\title{
Effect of Sea Surface Temperature and Chemical Parameters on the Metal Zn Contents in Inshore and Offshore Water of Blanakan Coast, West Java, Indonesia
}

\author{
Noverita Dian Takarina ${ }^{1}$ \\ \{noverita.dian@sci.ui.ac.id ${ }^{1}$ \} \\ Department of Biology, Faculty of Mathematics and Natural Sciences, Universitas Indonesia, Depok, \\ West Java, Indonesia ${ }^{1}$
}

\begin{abstract}
The Sea Surface Temperature (SST) is one of the prominent factors affecting metals concentration in the marine environment. Hence, this research is aiming to study the effect of SST on $\mathrm{Zn}$ content distribution in the seawater of Blanakan coast. The $\mathrm{Zn}$ was measured from sampled seawater collected from 7 stations were representing inshore and offshore of Blanakan coast. The sampled water then analyzed by AAS to obtain the $\mathrm{Zn}$ contents which confirms a positive effect of SST on $\mathrm{Zn}$ contents $(\mathrm{r} 2=0.18)$. An increase of SST from 25 to $31 \mathrm{oC}$ was followed by increase of $\mathrm{Zn}$ in seawater from 0.31 to $0.50 \mathrm{mg} / \mathrm{l}$ of water. Respectively, all $\mathrm{Zn}$ values in Blanakan coast have exceeded the permissible limit of EPA $(0.09 \mathrm{mg} / \mathrm{l}$ for seawater). Following the SST fluctuation, it is predicted that $\mathrm{Zn}$ in seawater will be higher in February-May and lower in July-September.
\end{abstract}

Keywords: Coast, Metal, Offshore, Sea Surface Temperature, Inshore

\section{Introduction}

Changes in marine environmental conditions include both natural events, for instance temperature fluctuations (long-term such as global warming, and short-term seasonal variations), and anthropogenic actions such as chemical contamination. Among pollutants, metals are of great importance. Their sources the aquatic environment are various, but significant contributions are man-made. Metals concentrations in marine environments are often relatively high [1].

The average concentrations of metals for example $\mathrm{Pb}, \mathrm{Cu}$, and $\mathrm{Cr}$ in the overlying water were very well correlated to the temperature fluctuations. There was an increase in $\mathrm{Zn}$ concentration following temperature increase. Respectively, when the temperature was increasing from 30 to $35^{\circ} \mathrm{C}$, the $\mathrm{Zn}$ was also increasing from 0.483 to $0.492 \mathrm{mg} / \mathrm{l}$ [2].

In the marine environment, the Sea Surface Temperature (SST) is a major parameter that can affect other parameters including biological and chemical properties of ecosystems. For example, the SST is having positive correlation with the chlorophyll a [3]. Furthermore, the ocean surface warming has been known can increase the $\mathrm{CO}_{2}$ [4].

Indonesia is a tropical country. The marine ecosystem in tropics is influenced by the dynamic of SST. Based on the data, the SST in Indonesia is ranging from 27 to $31{ }^{\circ} \mathrm{C}$ [5]. The maximum SST is observed from January to July and the minimum is from August to December [6]. In Java sea, the highest SST happens from April to November [7]. The SST fluctuation is ranging from 27.48 to $29.66{ }^{\circ} \mathrm{C}$. 
Even though the SST has received significant attentions, however body of literature discussing the relationship of SST with heavy metals in water of marine ecosystem is still limited. Hence, this paper aims to identify the effects of SST on heavy metals in particular Zn. The paper is also observing the relations of SST with heavy metals in seawater of various coastal ecosystems ranging from inshore to offshore. The Blanakan coast is chosen considering that the Blanakan is bordered directly with Java sea. Hence, information on SST and heavy metals in Blanakan coast can contribute to sustainable coastal management over there.

\section{Methodology}

The samples were collected from 7 stations that located in inshore and offshore of Blanakan coast. The sample collection activities were conducted in April 2019. The samples that collected and measured directly from the fields were sea surface temperature (SST), redox potential (Eh), dissolved oxygen (DO), pH, salinity, and turbidity. Moreover, seawater containing heavy metals were collected from the field to be transported to the laboratory for further analysis.

\subsection{Study Site}

The Blanakan coast is located in northern part of Subang district, West Java province. Figure 1 ilustrated the 7 stations geocoordinates were located from western part at latitude: 6.22691, longitude: 107.66431 (station 4) to eastern part at latitude: -6.23 , longitude: 107.67953 (station 7).

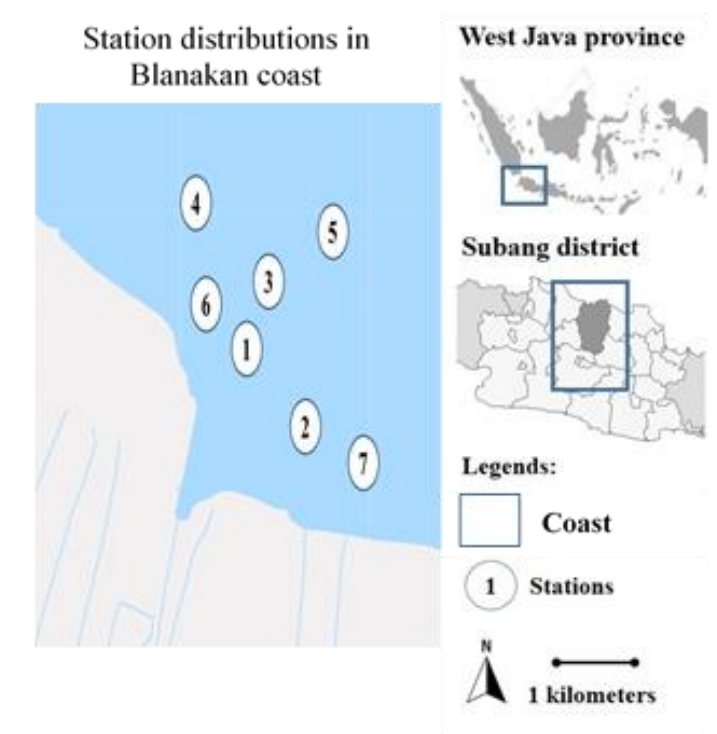

Fig. 1. Sampling location in Blanakan water include inshore and offshore.

The station 1, 2, 6 and 7 are representing inshore stations and 3, 4 and 5 are representing offshore stations. The offshore stations are bordered directly with the Java sea. The geocoordinates of 7 stations can be seen in Table 1 . 
Table 1. The geocoordinates of 7 stations representing inshore and offshore water of Blanakan coast.

\begin{tabular}{lll}
\hline Stations & Latitude & Longitude \\
\hline 1 & -6.2300 & 107.6699 \\
2 & -6.2304 & 107.6749 \\
3 & -6.2272 & 107.6702 \\
4 & -6.2269 & 107.6643 \\
5 & -6.2230 & 107.6731 \\
6 & -6.2302 & 107.6667 \\
7 & -6.2300 & 107.6795 \\
\hline
\end{tabular}

\subsection{Physico-chemical parameters measurements}

The parameters including SST, Eh, DO, pH, salinity and turbidity were measured directly in the seawater. DO and SST measured by using DO meter, ph and Eh with pH and ORP meter, salinity with refractometer and turbidity with turbidity meter respectively.

\subsection{Physico-chemical parameters mapping}

All the coordinates of physico-chemical parameters were recorded by using GPS. GIS software was used to map the physico-chemical parameters in the inshore and offshore of Blanakan coast. The map of physico-chemical parameters then overlayed with the Blanakan coast.

\subsection{Heavy metal sampling and analysis}

In the field, the seawater was sampled by using polyethylene bottle and kept in a cooler box to be transported to the laboratory. In the laboratory, the seawater sample was analyzed by using AAS to obtain the $\mathrm{Zn}$ values $[8,9]$.

\subsection{Statistical and factorial analysis}

$\mathrm{Mm}$ Correlation and factorial analysis were used to analyze the effects of SST on Zn contents in inshore and offshore water of Blanakan coast. The correlation test describes the correlation of station distance from the coast $(\mathrm{m})$ with the SST $\left({ }^{\circ} \mathrm{C}\right)$ and $\mathrm{Zn}$ contents $(\mathrm{mg} / \mathrm{l})$. The factorial test divides the Zn, SST, Eh, DO, pH, salinity and turbidity into Factor 1 and 2 depend on their correlation to each other.

\section{Result and Discussion}

The SST was ranging from 25 to $31{ }^{\circ} \mathrm{C}$. The SST in Java sea during period of April to November was also reported ranging from 27 to $31^{\circ} \mathrm{C}$ [7]. The Figure 2. A. shows that SST 
was a function of a distance from the coast. The higher SST was found in stations located far $(>1.000 \mathrm{~m})$ from the coast (offshore). Conversely, the stations near $(<600 \mathrm{~m})$ the shore (inshore) have lower SST. The low SST near coast is related to the Ekman transport [10]. When the Ekman transport occurs, the cold seawater from the bottom drawn up to surface and replace the warmer SST in the surface. Since the Ekman transport only occurs near the coast, hence only inshore SST that has lower temperature than SST in offshore that warmer (Figure 2. A). The $\mathrm{Zn}$ content was ranging from 0.25 to $0.45 \mathrm{mg} / \mathrm{l}$ inshore and 0.30 to $0.55 \mathrm{mg} / \mathrm{l}$ offshore. It means that lower higher $\mathrm{Zn}$ was found in stations near $(<600 \mathrm{~m})$ the shore (inshore). Conversely, the stations located far (>1.000 m) from coast (offshore) have higher Zn (Figure 2. B).

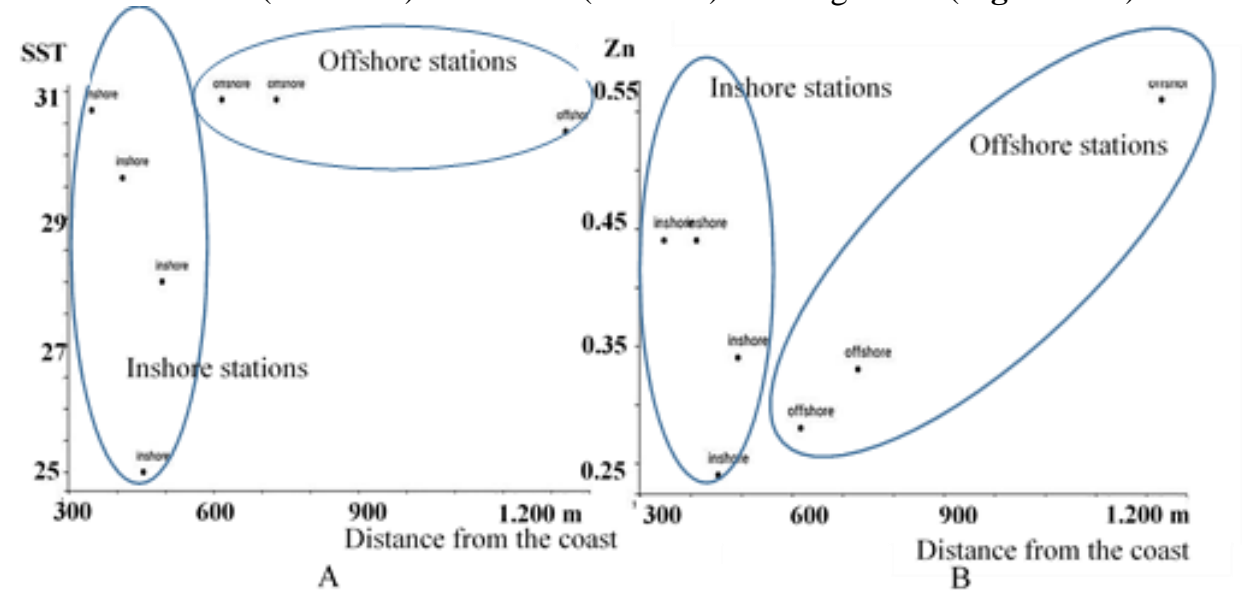

Fig. 2. A) The correlation of distance from the coast (m) with SST (oC), B) The correlation of distance from the coast (m) with $\mathrm{Zn}(\mathrm{mg} / \mathrm{l})$.

Table 2 informs the value of $\mathrm{Zn}$, SST and chemical parameters (DO, pH, Eh, salinity, turbidity) measured from 7 stations in Blanakan coast. From various physico-chemical parameters measured and based on factorial analysis, only SST and followed by salinity parameters that show strong correlation with Zn content (Figure 3).

Table 2. The values of Zn, SST and chemical parameters in 7 stations in Blanakan coast.

\begin{tabular}{|c|c|c|c|c|c|c|c|}
\hline \multirow[b]{2}{*}{ Stations } & \multirow{2}{*}{$\begin{array}{l}\mathrm{Zn} \\
(\mathrm{mg} / \mathrm{l})\end{array}$} & \multirow{2}{*}{$\begin{array}{l}\text { SST } \\
\left({ }^{0} \mathrm{C}\right)\end{array}$} & \multicolumn{5}{|c|}{ Chemical parameters } \\
\hline & & & $\begin{array}{l}\text { DO } \\
(\mathrm{mg} / \mathrm{l})\end{array}$ & $\mathrm{pH}$ & $\begin{array}{l}\text { Eh } \\
(\mathrm{mV})\end{array}$ & $\begin{array}{l}\text { Salinity } \\
\text { (ppt) }\end{array}$ & $\begin{array}{l}\text { Turbidity } \\
\text { (NTU) }\end{array}$ \\
\hline 1 & 0.24 & 25.00 & 5.76 & 7.51 & -27.66 & 15 & 178.53 \\
\hline 2 & 0.44 & 29.63 & 3.33 & 7.15 & -41.33 & 9 & 13.44 \\
\hline 3 & 0.33 & 30.86 & 3.5 & 7.46 & -20.00 & 14 & 80.13 \\
\hline 4 & 0.28 & 30.51 & 2.43 & 7.25 & -30.33 & 13 & 32.86 \\
\hline 5 & 0.55 & 30.33 & 4.60 & 7.52 & -43.66 & 21 & 24.53 \\
\hline 6 & 0.44 & 30.70 & 1.56 & 7.43 & -56.66 & 14 & 145.33 \\
\hline 7 & 0.34 & 31.00 & 1.16 & 7.53 & -51.00 & 17 & 218.03 \\
\hline
\end{tabular}




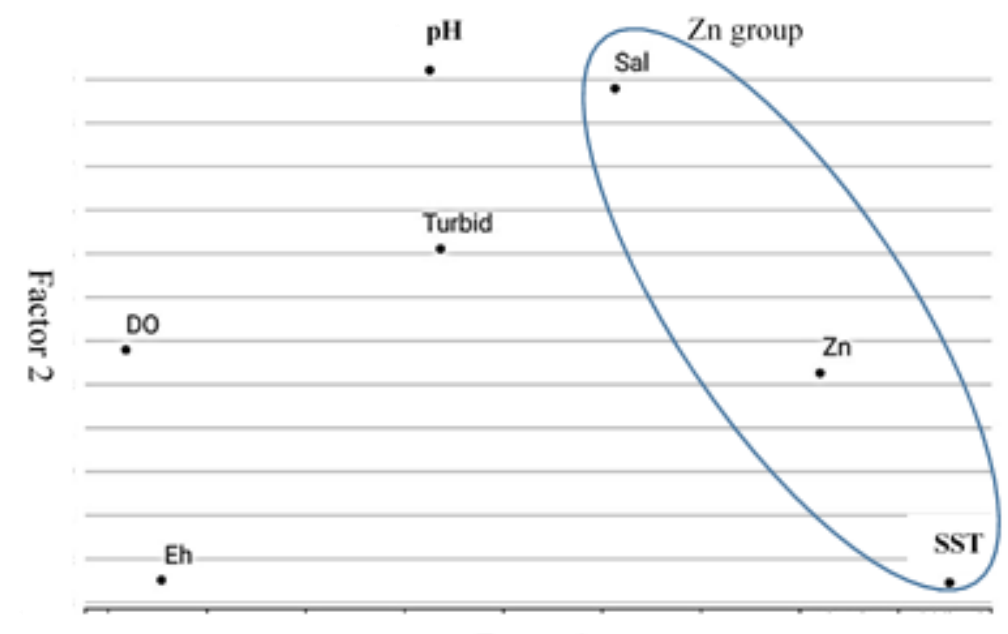

Factor 1

Fig. 3. The graphical plots of factorial analysis of Zn with SST and physico-chemical parameters in inshore and offshore water of Blanakan coast.

In a complex marine system, variations of any environmental factors is not independent. It will be interdepend with other environmental parameters, which can be analyzed by correlation method [11]. The correlation observed between SST and Zn is a positive correlation $\left(r^{2}=0.18\right)$. The increase of SST was followed by the increase of Zn contents (Figure 4). The rise of water temperature due to post monsoon was also reported has been followed by increase of $\mathrm{Zn}$ in water [12]. When the SST was increasing from 25 to $31{ }^{\circ} \mathrm{C}$, hence the $\mathrm{Zn}$ contents in seawater were also increased from 0.32 to $0.50 \mathrm{mg} / \mathrm{l}$. The $\mathrm{Zn}$ contents both in seawater of inshore and offshore have exceeded the $\mathrm{Zn}$ permissible limits for water, which is the limit is $0.09 \mathrm{mg} / \mathrm{l}$ for seawater [13].

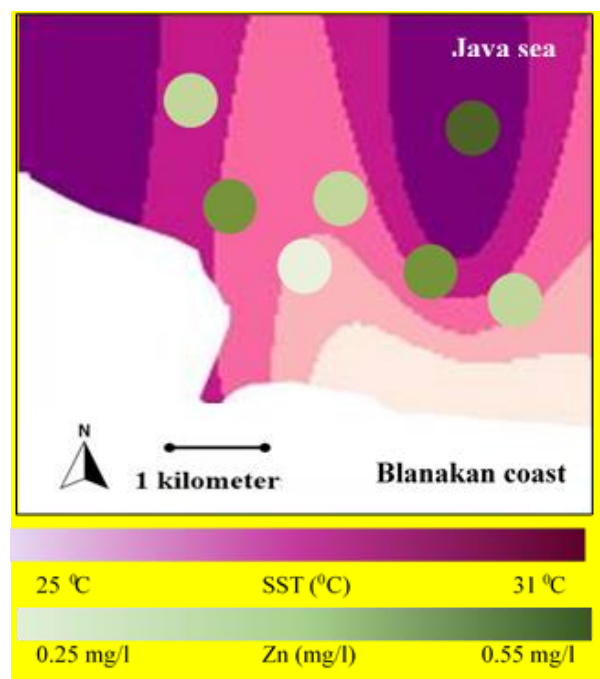

Fig. 4. The patterns of SST $(\mathrm{oC})$ and $\mathrm{Zn}(\mathrm{mg} / \mathrm{l})$ in inshore and offshore water of Blanakan coast. 
The correlation of SST with Zn can be modeled as $\mathrm{y}=0.0218 \mathrm{x}-0.2743$ (with $\mathrm{y}=\mathrm{Zn}$ and $\mathrm{x}=\mathrm{SST}$ ). By using that model and referenced SST (Figure 5. A), a 12 months Zn in seawater can be predicted (Figure 5. B). Based on the predicted $\mathrm{Zn}$, the $\mathrm{Zn}$ content in seawater is estimated ranging from 0.33 to $0.37 \mathrm{mg} / \mathrm{l}$. The highest $\mathrm{Zn}$ content is predicted will occur from February to May and the lowest Zn can be observed from July to September.

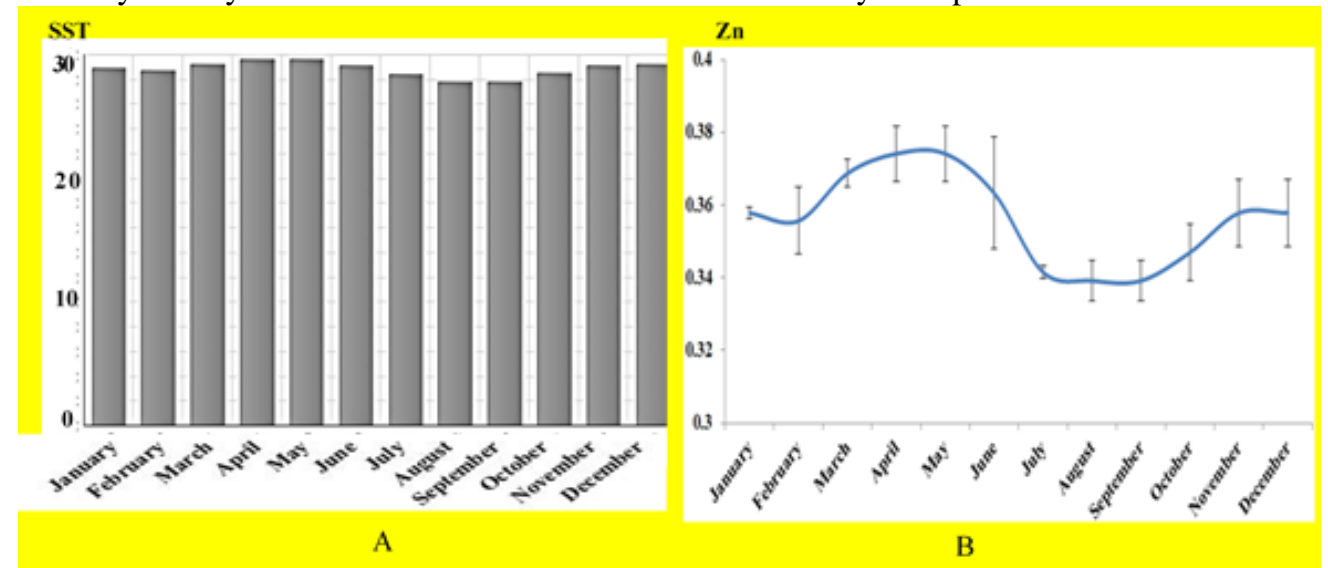

Fig. 5. A) The referenced SST (oC) in Java Sea, B) The 12-month Zn (mg/l) prediction in Blanakan coast.

\section{Conclusion}

The significant effect of SST on $\mathrm{Zn}$ in seawater of Blanakan coast can be observed in the offshore, but not in inshore. Only SST and followed by salinity parameters that show strong correlation with Zn contents. The rise in SST can increase the Zn contents. All the Zn contents in inshore and offshore water of Blanakan coast have exceeded the $\mathrm{Zn}$ permissible limit. Besides salinity, other chemical parameters like DO, pH, Eh and turbidity do not show effect and correlation as well with the Zn. The correlation between SST and Zn can be modeled. By using that model, a 12 months $\mathrm{Zn}$ in seawater can be predicted. The highest $\mathrm{Zn}$ content is predicted will occur from February to May and the lowest Zn can be observed from July to September.

Acknowledgement. This research is funding under PIT 9 scheme supported by DRPM UI with contract number NKB-0029/UN2.R3.1/HKP.05.00/2019.

\section{References}

[1] Pierre, S., Tarnowska, K., Hachfi, L., Coupei, S., Simidei, R., Couvray, S., Garnier, C., Grimaldi, M., Richr, S., Gaillardi, S., Prevot, N., Grillasca, J.P.: Effect of water temperature increase and heavy metals contamination on WAP65 gene expression in sea bass (Dicentrarchus labrax) liver. Cellular and molecular biology (Noisy-le-Grand, France) 57 Suppl. pp. 1614-1622 (2011) 
[2] Li, H., Shi, A., Li, M., Zhang, X.: 2013 Effect of pH, temperature, dissolved oxygen, and flow rate of overlying water on heavy metals release from storm sewer sediments. Journal of Chemistry Vol 2013. pp. 1-11 (2013)

[3] Nurdin, S., Mustapha, M.A., Lihan, T.: The relationship between sea surface temperature and chlorophyll-a concentration in fisheries aggregation area in the archipelagic waters of spermonde using satellite images. AIP Conference Proceedings 1571. pp 466-472 (2013)

[4] Kawatani, Y., Hamilton, K., Noda, A.: The effects of changes in sea surface temperature and CO2 concentration on the Quasi-Biennial oscillation. Journal of Atmospheric Science Vol 69. pp 1734-1749 (2012)

[5] Yunita, N.F., Zikra, M.: Variability of sea surface temperature in Indonesia based on Aqua Modis satellite data. IPTEK Journal of Engineering 3 (3). pp. 15-18 (2017)

[6] Corvianawatie, C., Putri, M.R., Cahyarini, S.Y., Tatipatta, W.M.: Variability of sea surface temperature and sea surface salinity in the Ambon bay and its relation to ENSO/IOD and monsoon Indonesia Journal of Geospatial 3 (2). pp. 1-8 (2014)

[7] Sulistya, W., Hartoko, A., Prayitno, B.: The characteristics and variability of SST in Java sea. International Jounal of Remote Sensing and Earth Sciences Vol 4. pp 85-93 (2007)

[8] Takarina, N.D., Bengen, D.G., Sanusi, H.S., Riani, E.: Bioconcentration factor of copper (Cu), lead $(\mathrm{Pb})$, and zinc $(\mathrm{Zn})$ in Anadara indica related to the water quality in coastal areas. Makara Journal of Science 17 (1). pp. 23-28 (2013)

[9] Takarina, N.D., Adiwibowo, A., Sunardi, Wardhana, W., Pin, G.P.: Bioconcentration of lead (Pb) in milkfish (Chanos chanos Forsk) related to the water quality in aquaculture ponds of Marunda, North Jakarta. Indonesia International Journal of Scientific and Research Publications 2 (12). pp. 1-5 (2012)

[10] Codron, F. : Ekman heat transport for slab ocean. Climate Dynamics 38 (1). pp. 379-389 (2011)

[11] Zhang, J., Zhou, F., Chen, C., Sun, X., Shi, Y., Zhao, H., Chen, F.: Spatial distribution and correlation characteristics of heavy metals in the seawater, suspended particulate matter and sediments in Zhanjiang Bay, China. Plos One 13 (8). pp. 1-25 (2018) 